\title{
UPAYA MENINGKATKAN PELAYANAN INFORMASI KEPADA MASYARAKAT MENGGUNAKAN MEDIA INTERAKTIF DI KANTOR SETDA KABUPATEN GROBOGAN
}

\author{
Dwi Puji Prabowo \\ Program Studi Desain Komunikasi Visual \\ Fakultas Ilmu Komputer, Universitas Dian Nuswantoro Semarang \\ Prabowo1989@gmail.com
}

\begin{abstract}
Abstrak
Kebutuhan masyarakat akan pelayanan informasi sangatlah penting, salah satunya adalah pelayanan publik yang memuasakan dapat menjadi indikasi bahwa pemerintahan di suatu daerah berjalan dengan baik. Perkembangan teknologi di era globalisasi sekarang ini sangatlah berkembang pesat. Kantor Setda Kabupaten Grobogan berupaya meningkatkan pelayanan publik dengan memanfaatkan teknologi yaitu menggunakan media interaktif sebagai sarana pemberian informasi kepada masyarakat. Penelitian ini juga memberikan konsep kreatif yang digunakan. Hasil yang dicapai pada penelitian ini menghasilkan media interaktif yang mampu menunjang peningkatan pelayanan kepada masyarakat. Dengan adanya media interaktif Sistem Informasi Publik diharapkan masyarakat dapat memperoleh informasi dengan mudah dan valid serta tingkat kepuasan masyarakat terhadap pelayanan semakin meningkat guna menunjang kemajuan pembangunan daerah.
\end{abstract}

Kata Kunci: Pelayanan publik , multimedia, media interaktif

\section{PENDAHULUAN}

Pelayanan publik merupakan salah satu kebutuhan yang sangat penting bagi masyarakat dalam memperoleh informasi. (Rahardjo Adisasmita, 2011) Pelayanan Publik merupakan kegiatan yang dilaksanakan oleh penyelenggara pelayanan publik sebagai upaya pemenuhan kebutuhan penerima pelayanan, dalam pelaksanaan ketentuan peraturan perundang-undangan. Peningkatan pelayanan publik yang efisien dan efektif akan mendukung tercapainya efisiensi dan efektif akan mendukung tercapainya efisiensi pembiayaan.

Undang-Undang Pelayanan Publik (secara resmi bernama Undang-Undang Nomor 25 Tahun 2009 tentang Pelayanan Publik) adalah undang-undang yang mengatur tentang prinsip-prinsip pemerintahan yang baik yang merupakan efektifitas fungsi-fungsi pemerintahan itu sendiri. Salah satu bentuk pelayanan publik adalah SIM Publik yang memberikan informasi kepada masyarakat tentang kegiatan dan data-data yang dapat dipakai untuk kepentingan umum. Pada era globalisasi sarana informasi dan komunikasi mulai berkembang pesat dengan memanfaatkan media-media digital yang berbasis komputerisasi seperti penggunaan layar sentuh untuk menampilkan aplikasi system yang bersifat komputerisasi akan membuat masyarakat tidak canggung dalam memperoleh informasi yang dibutuhkan karena informasi yang akan dicari akan didapat dalam satu perangkat komputerisasi yang sudah dirancang sedemikian rupa sehingga masyarakat bisa berinteraksi dengan baik. Pada penggunaan media informasi menggunakan media komputerisasi akan memberikan dampak efek yang signifikan 
dalam pelayanan publik kepada masyarakat. Pemanfaatan dan penerapan menggunakan teknologi dalam mengoptimalkan pelayanan publik akan membantu instansi swasta atau pemerintah dalam mewujudkan kepuasan pelayanan kepada masyarakat.

Kabupaten Grobogan merupakan kabupaten terluas kedua di Jawa Tengah setelah Kabupaten Cilacap, dan berbatasan langsung dengan 9 kabupaten lain. Letak astronomis wilayah antara $110^{\circ} 15^{\prime} \mathrm{BT}-111^{\circ} 25^{\prime} \mathrm{BT}$ dan $7^{\circ} \mathrm{LS}-7^{\circ} 30^{\prime} \mathrm{LS}$, dengan jarak bentang dari utara ke selatan $\pm 37 \mathrm{~km}$ dan dari barat ke timur $\pm 83 \mathrm{~km}$. Dengan wilayah seluas itu diperluakan berbagai instansi-instansi pemerintahan yang menanganinya disetiap bidang seperti masalah pertanian, perhubungan, perikanan, perkebunan, pariwisata dan lain-lain.

Kantor setda merupakan salah satu instansi pemerintah yang yang memiliki bangunan dengan 3 lantai dan di dalam bangunan tersebut terdapat beberapa kantor pusat informasi dari instansi-instansi pemerintah dimana data kegiatan dan hasil-hasil kekayaan yang dikelola ada disana. Untuk mendapatkan informasi tentang kabupaten grobogan, selama ini masyarakat bisa langsung mengakses melalui website kabupaten grobogan, namun masyarakat harus terhubung dengan internet. Padahal tidak semua lapisan masyarakat di kabupaten grobogan mampu menggunakan internet sehingga masyarakat yang tidak paham internet tidak bisa mengakses informasi website. Selain itu masyarakat bisa datang langsung ke kantor setda dan menanyakanya informasi yang dibutuhkan ke bagian instansinya secara langsung. Permasalahan yang muncul ketika masyarakat ingin mendapatkan informasi secara langsung ke kantor setda, terkadang masyarakat bingung harus menanyakan kepada siapa tentang informasi yang dibutuhkan, biasanya ketika masyarakat masuk ke kantor setda pasti pertama dilantai 1 akan disambut oleh resepsionis yang hanya mengarahkan masyarakat ke bagian instansi yang akan dituju. Sebenarnya fungsi resepsionis yang diharapkan masyarakat adalah mampu memberi keterangan secara jelas dan benar tentang data yang diperlukan oleh masyarakat, namun tidak mungkin untuk seorang resepsionis bisa menghafalkan dan memahami data-data disetiap instansi yang ada di kantor tersebut. Maka dari itu untuk mengatasi hal tersebut perlu pengembangan pelayanan informasi publik yang bisa diakses secara offline dan berbasis interaktif media agar masyarakat dapat mengakses informasi tanpa kesulitan sehingga kepuasan pelayanan publik menjadi meningkat.

Sistem informasi publik menggunakan Interaktif media secara offline dengan memanfaatkan media LED televisi layar sentuh merupakan salah satu media yang sekarang ini berkembang sebagai opsi dimana interaktif media ini juga mampu menggantikan peranan manusia dalam berinteraksi secara langsung. Kelebihan interaktif media adalah masyarakat dapat langsung berinteraksi secara offline dan memperoleh informasi secara menyeluruh dan mudah. Jadi dari latar belakang diatas maka diambil tema Aplikasi Media Interaktif Dalam Upaya Meningkatkan Pelayanan Informasi Kepada Masyarakat Di Kantor Setda Kabupaten Grobogan. 


\section{TINJAUAN PUSTAKA}

\subsection{Pelayanan Publik}

Pelayanan publik di Indonesia mempunyai peran penting bahkan vital pada kehidupan ekonomi dan politik. Pelayanan publik juga merupakan unsur paling penting dalam meningkatkan kualitas hidup sosial di dalam masyarakat manapun. Secara ideal, tujuan utama pemerintah tersebut berada (Saragih, 2006). mengingat pelayanan publik memiliki implikasi yang luas dalam kehidupan ekonomi dan politik. Tetapi, kualitas pelayanan publik sampai saat ini secara umum masih belum baik. Buruknya kualitas pelayanan publik menimbulkan krisis kepercayaan di masyarakat terhadap birokrasi publik. Krisis kepercayaan ditunjukkan dengan munculnya berbagai bentuk protes dan demonstrasi kepada birokrasi baik di tingkat pusat maupun di daerah (Dwiyanto, 2006).

Reformasi pelayanan publik sendiri merupakan prime mover (penggerak utama) yang dinilai strategis untuk memulai pembaharuan praktik governance(Dwiyanto, 2005). Reformasi pelayanan publik dinilai sebagai entry point dan penggerak utama karena upaya untuk mewujudkan nilai-nilai yang selama ini mencirikan praktik governance yang baik dalam pelayanan publik dapat dilakukan secara lebih nyata dan mudah. Produk dari pela-yanan publik didalam negara demokrasi paling tidak harus memenuhi tiga indikator, yakni responsiveness, responsibility, dan accountability (Lenvine, 1990)

\subsection{Pengertian Media}

Media adalah sebuah alat yang mempunyai fungsi menyampaikan pesan (Bovee, 1997). Bentuk-bentuk stimulus bisa dipergunakan sebagai media diantaranya adalah hubungan atau interaksi manusia, realita, gambar bergerak atau tidak, tulisan dan suara yang direkam. Secara luas media dapat diartikan sebagai alat perantara untuk menyampaiakn satu pesan kepada audience dalam bentuk penyajian informasi apapun. Kata media berasal dari bahasa latin dan merupakan bentuk jamak dari kata medium yang secara harfiah berarti perantara atau pengantar. Media adalah segala sesuatu yang dapat digunakan untuk menyalurkan pesan dari pengirim ke penerima sehingga dapat merangsang pikiran, perasaan, perhatian, dan minat serta perhatian audience sedemikian rupa sehingga proses komunikasi terjadi (Sadiman,2002:6).

\subsection{Multimedia Interaktif}

Secara etimologis multimedia berasal dari kata multi (Bahasa Latin, nouns) yang berarti banyak, bermacam-macam, dan medium (Bahasa Latin) yang berarti sesuatu yang dipakai untuk menyampaikan atau membawa sesuatu. Kata medium dalam American Heritage Electronic Dictionary (1991) juga diartikan sebagai alat untuk mendistribusikan dan mempresentasikan informasi (Rachmat dan Alphone, 2005/2006). Beberapa definisi multimedia menurut beberapa ahli diantaranya:

1. Kombinasi dari paling sedikit dua media input atau output. Media ini dapat berupa audio (suara, musik), animasi, video, teks, grafik dan gambar (Turban dkk, 2002)

2. Alat yang dapat menciptakan presentasi yang dinamis dan interaktif yang mengkombinasikan teks, grafik, animasi, audio dan video (Robin dan Linda, 2001) 
3. Multimedia dalam konteks komputer menurut Hofstetter (2001) adalah: pemanfaatan komputer untuk membuat dan menggabungkan teks, grafik, audio, video, dengan menggunakan tool yang memungkinkan pemakai berinteraksi, berkreasi, dan berkomunikasi.

4. Multimedia sebagai perpaduan antara teks, grafik, sound, animasi, dan video untuk menyampaikan pesan kepada publik (Wahono, 2007)

5. Multimedia merupakan kombinasi dari data text, audio, gambar, animasi, video, dan interaksi (Zeembry, 2008)

6. Multimedia (sebagai kata sifat) adalah media elektronik untuk menyimpan dan menampilkan data-data multimedia (Zeembry, 2008)

Berdasarkan pendapat-pendapat tersebut maka dapat disimpulkan bahwa multimedia merupakan perpaduan antara berbagai media (format file) yang berupa teks, gambar (vektor atau bitmap), grafik, sound, animasi, video, interaksi, dll.yang telah dikemas menjadi file digital (komputerisasi), digunakan untuk menyampaikan pesan kepada publik.

\subsection{Teori Komunikasi}

\subsubsection{Definisi Komunikasi}

Komunikasi adalah saluran untuk melakukan dan menerima pengaruh mekanisme perubahan alat untuk mendorong mempertinggi motivasi dan juga perantara serta sarana dimana kemungkinan suatu organisasi mencapai tujuannya. Komunikasi terbagi menjadi dua yaitu verbal dan non verbal. Komunikasi verbal yaitu suatu proses komunikasi dengan menggunakan symbol atau lambang - lambang. Simbol - simbol yang digunakan selain sudah ada yang diterima menurut konvensi internasional seperti simbol lalu lintas, alfabet latin, symbol matematika, juga terdapat simbol - simbol lokal yang hanya bisa di mengerti oleh kelompok - kelompok masyarakat tertentu. Sedangkan komunikasi non verbal adalah proses komunikasi dengan menggunakan kode non verbal. Kode nonverbal ini biasa disebut dengan bahasa isyarat atau bahasa diam (silent language), maupun bahasa tubuh (body language).

\subsubsection{Proses Komunikasi}

Berangkat dari paradigma Laswell, Effendy (1994:11-9) membedakan proses komunikasi menjadi dua tahap, yaitu :

a. Proses komunikasi secara primer

Proses komunikasi secara primer adalah proses penyampaian pikiran dan atau perasaan seseorang kepada orang lain dengan menggunakan lambang (symbol) sebagai media. Lambang sebagai media primer dalam proses komunikasi adalah pesan verbal (bahasa), dan pesan non verbal (kial, gesture, isyarat, gambar, warna, dan lain sebagainya) yang secara langsung dapat atau mampu menerjemahkan pikiran dan atau perasaan komunikator kepada komunikan.

b. Proses komunikasi secara sekunder

Proses komunikasi secara sekunder adalah proses penyampaian pesan oleh komunikator kepada komunikan dengan menggunakan alat atau sarana sebagai media kedua setelah memakai lambang sebagai media pertama. 


\section{METODE PENELITIAN}

\section{a. Metode Pengumpulan Data}

Sebelum melakukan rancangan penelitian maka harus dicari data untuk kebutuhan penelitian. Data yang akan digunakan ada tiga macam:

a. Studi Pustaka

Metode pengumpulan data dengan mencari, membaca buku-buku, artikel terkait dari media cetak, internet untuk memperoleh informasi.

b. Wawancara

Wawancara dilakukan cara melakukan wawancara langsung dan komunikasi dengan pengelola kantor setda bagian PDE Kabupaten Grobogan .

c. Dokumentasi

Data yang didapat baik dari kantor setda Kabupaten Grobogan yang diharap dapat membantu dalam proses pembuatan aplikasi media interaktif untuk membantu meningkatkan pelayanan informasi publik. Dokumentasi ini berupa buku, gambar, foto, dan arsip yang berhubungan dengan permasalahan yang diangkat. Gambar yang relevan yang nantinya dapat membantu penulis dalam mendapatkan data yang diharapkan, hal ini guna mendukung keakuratan data yang didapat.

\section{b. Metode Analisa Data}

Metode analisis yang digunakan adalah framing, dimana dalam framing nanti akan dipaparkan relita-realita yang terjadi mengenai sistem informasi dalam pelayanan publik, sebagaimana dipaparkan dalam tabel framing berikut:

\begin{tabular}{|l|l|l|l|}
\hline \multicolumn{1}{|c|}{ Realita } & \multicolumn{1}{|c|}{ Ideal } & \multicolumn{1}{c|}{ Sebab } & \multicolumn{1}{c|}{ Statement } \\
\hline $\begin{array}{l}\text { Publik kesulitan } \\
\text { mencari informasi } \\
\text { yang dibutuhkan } \\
\text { mengenai data- } \\
\text { data dan } \\
\text { perkembangan } \\
\text { yang terjadi di } \\
\text { pemerintahan kab } \\
\text { grobogan . }\end{array}$ & $\begin{array}{l}\text { Publik mudah } \\
\text { mendapatkan } \\
\text { informasi } \\
\text { mengenai data- } \\
\text { data dan } \\
\text { perkembangan } \\
\text { yang terjadi di } \\
\text { pemerintahan } \\
\text { kab. grobogan. }\end{array}$ & $\begin{array}{l}\text { Pelayanan publik } \\
\text { yang belum } \\
\text { maksimal } \\
\text { menjadikan } \\
\text { informasi yang } \\
\text { dibutuhkan } \\
\text { masyarakat menjadi } \\
\text { sulit didapatkan. }\end{array}$ & $\begin{array}{l}\text { Dibutuhkan } \\
\text { peningkatan } \\
\text { pelayanan publik guna } \\
\text { memudahkan } \\
\text { masyarakat dalam } \\
\text { memperoleh informasi } \\
\text { yang cepat dan akurat. }\end{array}$ \\
\hline $\begin{array}{l}\text { Ketidak } \\
\text { nyamanan dalam } \\
\text { memperoleh } \\
\text { informasi yang } \\
\text { dikehendaki. }\end{array}$ & $\begin{array}{l}\text { Kenyamanan } \\
\text { diperlukan dalam } \\
\text { dalam } \\
\text { memperoleh } \\
\text { informasi dan } \\
\text { pelayanan publik. }\end{array}$ & $\begin{array}{l}\text { Rasa canggung atau } \\
\text { sungkan (pakewuh } \\
\text { dalam bahasa jawa) } \\
\text { ketika terlalu banyak } \\
\text { bertanya kepada } \\
\text { petugas } \\
\text { pemerintahan. }\end{array}$ & $\begin{array}{l}\text { Diperlukan sebuah } \\
\text { media yang mampu } \\
\text { memberikan } \\
\text { kenyamanan kepada } \\
\text { masyarakat karena } \\
\text { adanya perasaan } \\
\text { canggung ataupun } \\
\text { sungkan dalam } \\
\text { memperoleh informasi } \\
\text { yang diharapkan }\end{array}$ \\
\hline
\end{tabular}




\begin{tabular}{|c|c|c|c|}
\hline Realita & Ideal & Sebab & Statement \\
\hline $\begin{array}{l}\text { Kemampuan } \\
\text { resepsionis } \\
\text { sebagai manusia } \\
\text { sangat terbatas, } \\
\text { dalam arti } \\
\text { resepsionis hanya } \\
\text { akan memberikan } \\
\text { informasi yang } \\
\text { diketahui dalam } \\
\text { melakukan } \\
\text { pelayanan kepada } \\
\text { masyarakat.sehin } \\
\text { gga pelayanan } \\
\text { kepada } \\
\text { masyarakat tidak } \\
\text { masimal. }\end{array}$ & $\begin{array}{l}\text { Resepsionis } \\
\text { sebagai manusia } \\
\text { yang memiliki } \\
\text { kemampuan yang } \\
\text { terbatas dapat } \\
\text { dibantu dengan } \\
\text { adanya sebuah } \\
\text { system yang dapat } \\
\text { memberikan } \\
\text { pelayanan kepada } \\
\text { masyarakat, } \\
\text { sehingga } \\
\text { pelayanan kepada } \\
\text { masyarakat } \\
\text { menjadi maksimal. }\end{array}$ & $\begin{array}{l}\text { Minimnya fasilitas } \\
\text { penunjang yang bisa } \\
\text { membantu } \\
\text { resepsionis dalam } \\
\text { melakukan } \\
\text { pelayanan secara } \\
\text { maksimal kepada } \\
\text { masyarakat. }\end{array}$ & $\begin{array}{l}\text { Dibutuhkan sebuah } \\
\text { system yang mampu } \\
\text { memberikan informasi } \\
\text { yang menyeluruh } \\
\text { kepada masyarakat. }\end{array}$ \\
\hline $\begin{array}{l}\text { penggunaan web } \\
\text { sebagai sarana } \\
\text { penunjang dalam } \\
\text { pelayanan publik } \\
\text { kurang maksimal } \\
\text { karena bersifat } \\
\text { online. }\end{array}$ & $\begin{array}{l}\text { Penggunaan } \\
\text { media web yang } \\
\text { didukung dengan } \\
\text { media lain yang } \\
\text { sifatnya offline } \\
\text { tanpa } \\
\text { menggunakan } \\
\text { internet sehingga } \\
\text { masyarakat dapat } \\
\text { memperoleh } \\
\text { pelayanan dapat } \\
\text { berjalan dengan } \\
\text { baik. }\end{array}$ & $\begin{array}{l}\text { Sumber daya } \\
\text { manusia akan } \\
\text { kemajuan teknologi } \\
\text { yang tidak merata. }\end{array}$ & $\begin{array}{l}\text { Perlunya media } \\
\text { interaktif dalam } \\
\text { pelayanan publik } \\
\text { secara offline } \\
\text { sehingga semua } \\
\text { lapisan masyarakat } \\
\text { dapat memperoleh } \\
\text { informasi dengan } \\
\text { baik. }\end{array}$ \\
\hline
\end{tabular}

Dari framing isu diatas didapatkan beberapa statement yang menjadi konsep dalam pembuatan interaktif media sebagai berikut:

1. Masih dibutuhkan peningkatan pelayan publik yang mampu memudahkan masyarakat dalam memperoleh informasi .

2. Diperlukannya media yang mampu memberikan kenyamanan kepada masyarakat dalam memperoleh informasi.

3. Dibutuhkannya sebuah system yang mampu memberikan informasi yang menyeluruh kepada masyarakat.

4. Diperlukannya media interaktif dalam pelayanan publik secara offline sehingga informasi dapat diakses semua lapisan masyarakat.

Kemudian dari data framing diatas, dilakukan observasi untuk mendapatkan visualisasi dalam perancangan media interaktif agar bisa mendukung dalam meningkatkan pelayanan terhadap masyarakat. Wawancara dilakukan kepada instansi 
terkait serta masyarakat sekitar yang sering berkunjung ke instansi untuk memperoleh data pemasalahan yang dialami selama ini dan untuk mendapatkan solusi dari permasalahan yang dihadapi selama ini.

\section{HASIL DAN PEMBAHASAN}

\subsection{Strategi Analisa Perancangan Media}

Hasil analisis perancangan sistem informasi publik dengan media yang akan dibuat adalah menggunakan aplikasi media interaktif yang menggunakan program flas dengan memanfaatkan kemajuan teknologi LED TV layar sentuh sehingga diharapkan masyarakat dapat memperoleh informasi dengan mudah dan tanpa canggung untuk bertanya kepada resepsionis yang ada, serta dengan adanya media interaktif ini informasi yang akan didapatkan lebih valid.

\subsection{Konsep Kreatif}

\section{a) Tujuan}

Adapun tujuan dari konsep kreatif yaitu memberikan kesan nyaman ketika membuka dan membaca informasi yang ada di Sistem informasi Publik melalui LED TV layar sentuh serta pada tampilannya juga akan diberikan space untuk memberi ruang pengumuman kepada karyawan dan masyarakat.

\section{b) Strategi Kreatif}

\section{1) Target Sasaran}

Target sasaran primer adalah masyarakat umum dan karyawan yang berada di lingkungan area kantor Setda Kabupaten Grobogan.

2) Isi Pesan

Isi pesan berisi tentang informasi, data-data secara umum tentang kabupaten grobogan, kegiatan-kegiatan yang dilaksanankan oleh pimpinan daerah serta susunan jabatan struktural perangkat pejabat di Kabupaten Grobogan.

3) Bentuk Pesan

Bentuk pesan yang disampaikan adalah Pesan Non Verbal (Visual) .Pesan non verbal yang akan ditampilkan dalam perancangan ini adalah dengan memanfaatkan beberapa elemen desain seperti gambar, warna, teks dan elemen penyusul lainnya sebagai Poin of Interest (POI).

4) Tema Pesan

Tema pesan untuk media promosi yang akan ditampilkan adalah dengan memanfaatkan beberapa gambar, warna dan elemen penyusun lainnya serta wujud atau tampilan antarmuka dari Sistem Informasi Publik itu sendiri baik secara keseluruhan maupun sebagian.

\section{c) Program Kreatif}

1) Tema Visual

Tema visual yang ditampilkan merupakan desain yang simple serta menggunakan ikon-ikon yang disesuaikan dengan informasi yang akan ditampilkan sehingga mudah di pahami oleh pengguna serta menggunakan warna dominan biru untuk menu dan putih sebagai background. 


\section{2) Tipografi}

Pada pemilihan huruf dalam sebuah media sangatlah penting karena jenis huruf yang digunakan akan memiliki pengaruh terhadap si pengguna, dimana jenis huruf yang digunakan dalam mendesain aplikasi nantinya adalah jenis huruf sans-serif yaitu myriad pro dan century gothic karena sangat baik digunakan di dalam media screen, atau web, pad, tablet \& Icd monitor.

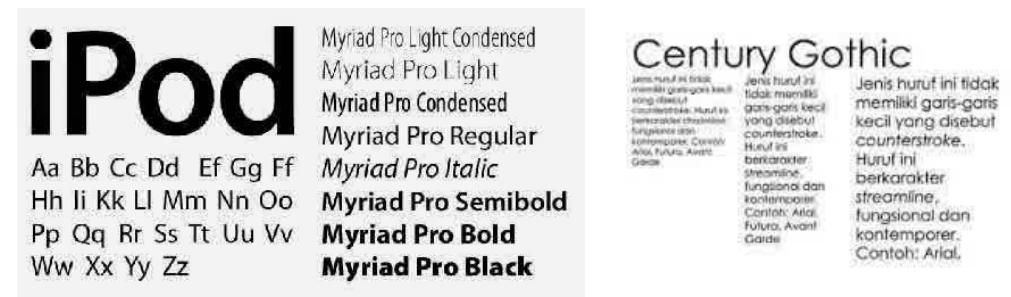

Gambar 1. Contoh Huruf San Serif

3) Pemilihan Warna

Warna yang digunakan adalah warna biru, orange dan putih, dimana setiap penggunaan warna memiliki sebuah makna. Warna biru menunjukan bahwa instansi pemerintah yang ada adalah instansi pemerintah yang dapat dipercaya dan mampu menaungi masyarakatnya dengan baik, warna orange menunjukan makna bahwa instansi pemerintah memiliki semangat dalam mewujudkan kemajuan pembangunan daerah Kabupaten Grobogan, warna putih merupakan warna netral yang mampu memberikan sebuah nilai estetika tersendiri.

\subsection{Visualisasi}

Pada bagian ini akan menampilakan visualisasi media berbasis multimedia, dalam hal ini dalam pembuatan aplikasi interaktif media Sistem Informasi Publik kantor Setda Kabupaten Grobogan.

a) Flowchart (Bagan Alir)

Dalam aplikasi Sistem informasi Publik terdapat 7 menu utama yang akan mencakup yang nantinya disetiap menu utama akan ada sub menu didalamnya karena penyusunan menu disesuaikan dengan bidang masing-masing.

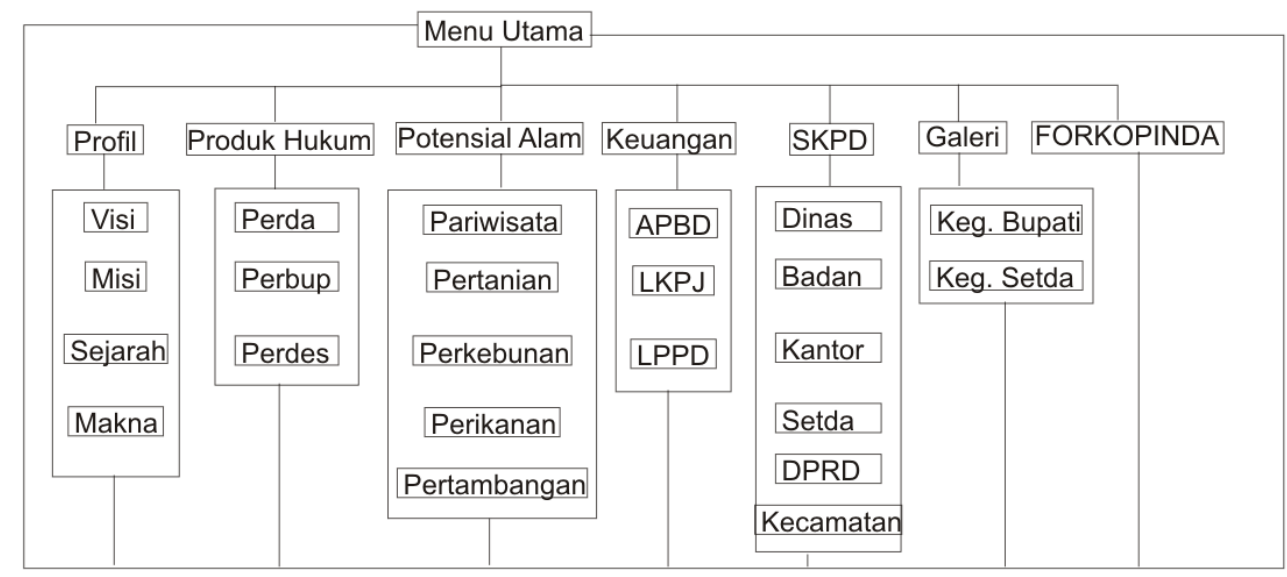

Gambar 2. Bagan Alir Aplikasi 
Gambar di atas adalah gambar bagan alir yang digunakan dalam aplikasi Sistem Informasi Publik Kantor Setda Kabupaten Grobogan. Pada menu profil berisi sub menu Visi, Misi, Sejarah, Makna Lambang dari kabupaten grobogan, sehingga ketika pengunjung nantinya mengklik menu profil maka yang akan muncul adalah sub menu tentang profil Kabupaten Grobogan. Pada menu Produk hukum berisi sub menu tentang produk hukum seperti Perda, Perbup, dan Perdes, dimana ketika pengunjung meng klik menu ini, pengunjung akan disediakan menu tentang produkproduk hukum yang ada di Kabupaten Grobogan. Pada menu Keuangan berisi tentang sub menu APBD, LKPJ, dan LPPD yang merupakan sub menu yang disediakan data yang berhubungan dengan keuangan, pengeluaran, pelaksanaan serta laporan-laporan keuangan yang telah digunkan dalam pembangunan daerah Kabupaten Grobogan. Pada menu SKPD berisi tentang Submenu Dinas, badan, Kantor, Setda, DPRD, Kecamatan pada setiap menu ini menampilkan tentang struktur organisasi di setiap badan organisasi dan dinas-dinas yang ada di Kabupaten Grobogan. Pada menu Galeri berisi tentang sub menu kegiatan bupati/wakil bupati dan kegiatan Setda, dimana pada sub menu tersebut apa bila pengunjung mengklik akan muncul dokumentasi foto kegiatan bupati/wakil bupati serta setda selama masa kerja. Menu terakhir pada menu utama adalah menu MUSKOPINDA adalah menu dimana pengunjung akan mendapatkan informasi dokumentasi tentang foto kegiatan dari musyawarah pimpinan daerah Kabupaten grobogan.

b) Visualisasi Ikon/Tombol

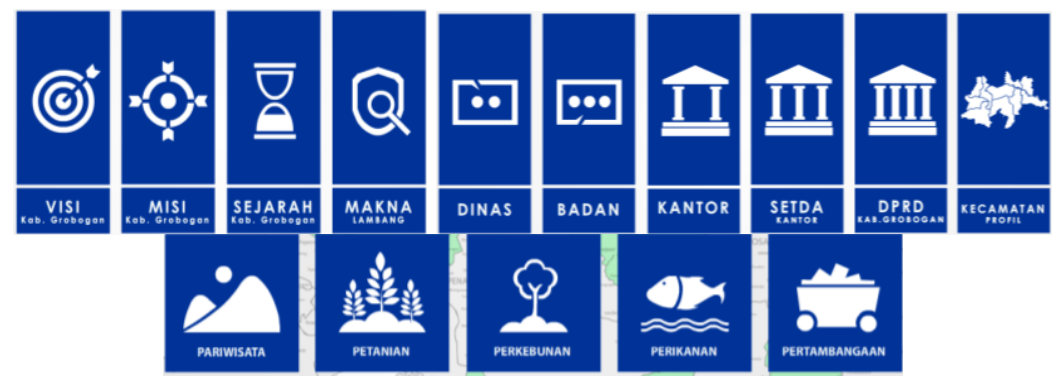

Gambar 3. Ikon tombol dalam aplikasi

c) Tampilan Menu Utama

Tampilan menu utama menampilkan visualisasi logo lambang kab. Grobogan, foto pejabat, ikon-ikon menu utama serta kolom untuk menyampaikan informasi .

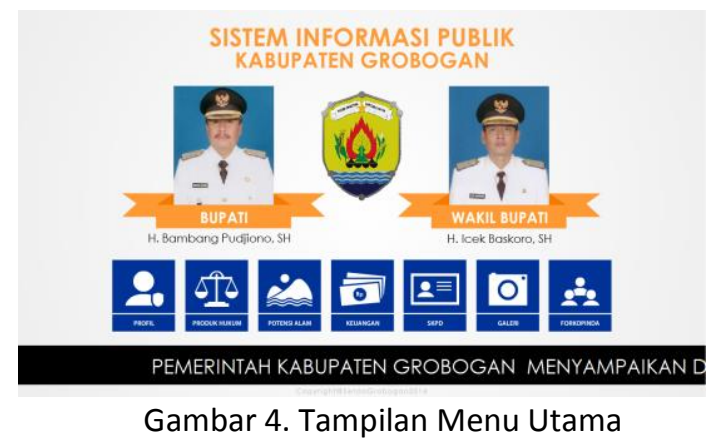


d) Tampilan menu profil

Dalam menu profil terdapat sub menu visi, misi, sejarah dan makna lambang Kab. Grobogan

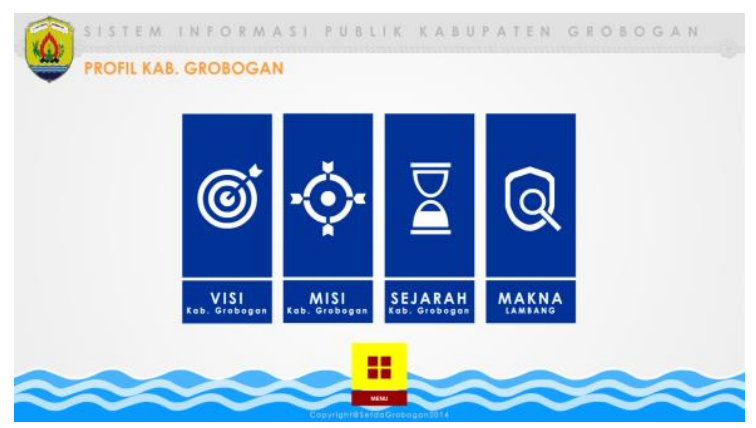

Gambar 5. Tampilan Menu Profil

e) Menu Produk Hukum

Menu produk hukum berisi tentang sub-sub menu tentang produk hukum, baik produk hukum perda, perbub dan perdes.

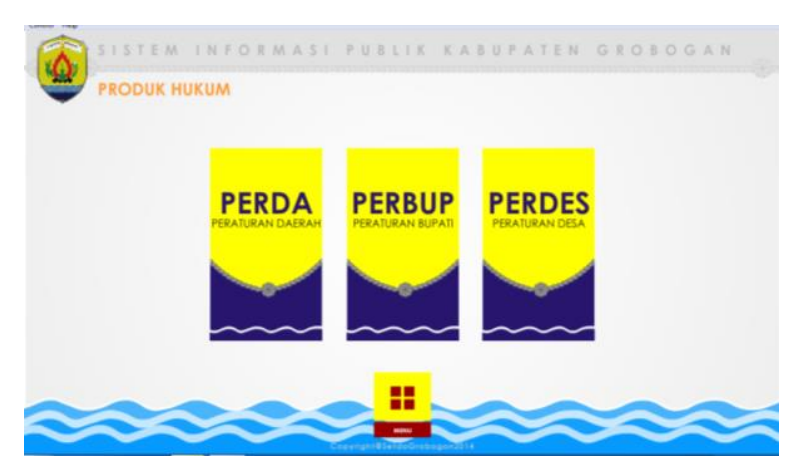

Gambar 6. Tampilan Menu Produk Hukum

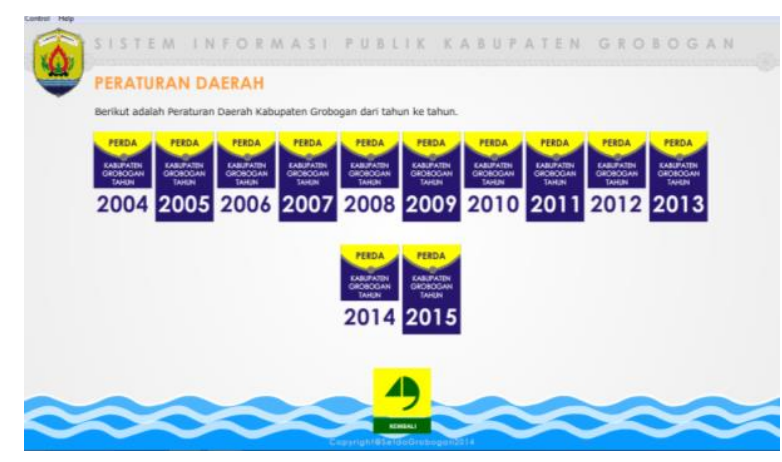

Gambar 7. Tampilan Sub Menu Perda

f) Menu Potensi Alam

Menu ini berisi tentang potensi-potensi alam yang ada diwilayah Kab.Grobogan diantaranya yaitu pariwisata, pertanian, perkebunan, perikanan dan pertambangan. 


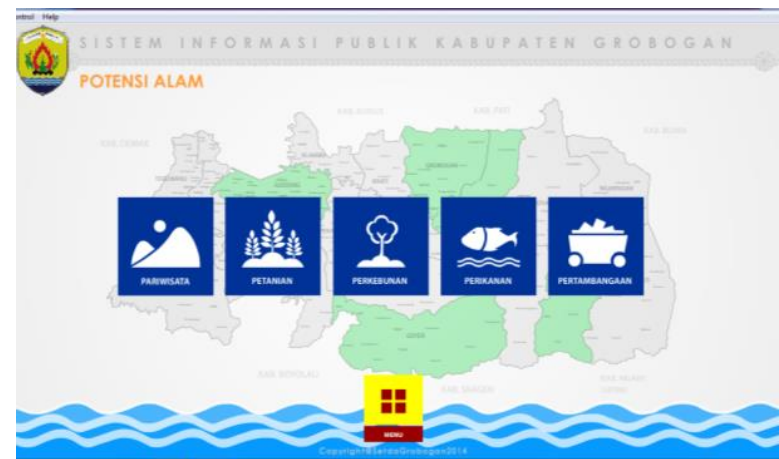

Gambar 8. Tampilan Menu Potensi Alam

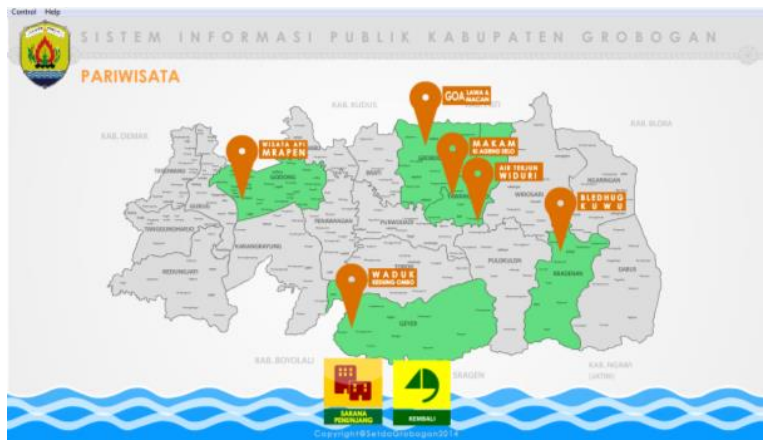

Gambar 9. Tampilan Sub Menu Pariwisata

g) Menu Keuangan

Menu ini berisi mengenai keuangan daerah kab. Grobogan

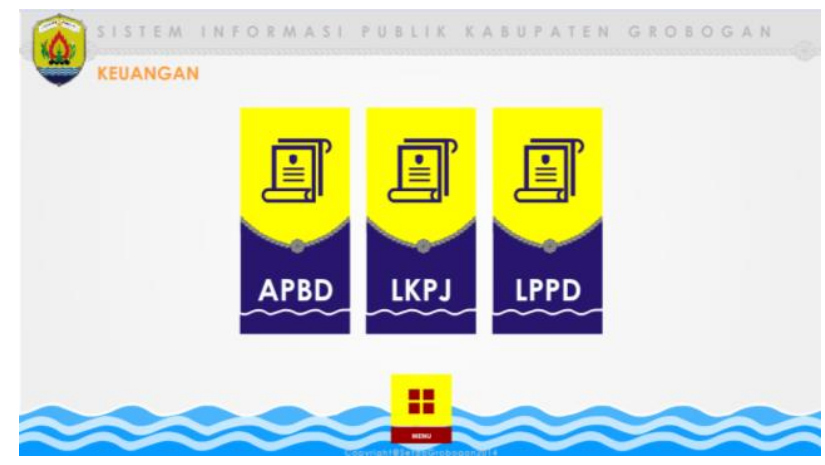

Gambar 10. Tampilan Menu Keuangan

h) Menu SKPD

Menu ini berisi tentang instansi-instansi pemerintah seperti dinas, badan, kantor, setda, DPRD dan kecamatan yang menjalankan pemerintahan di kab. Grobogan 


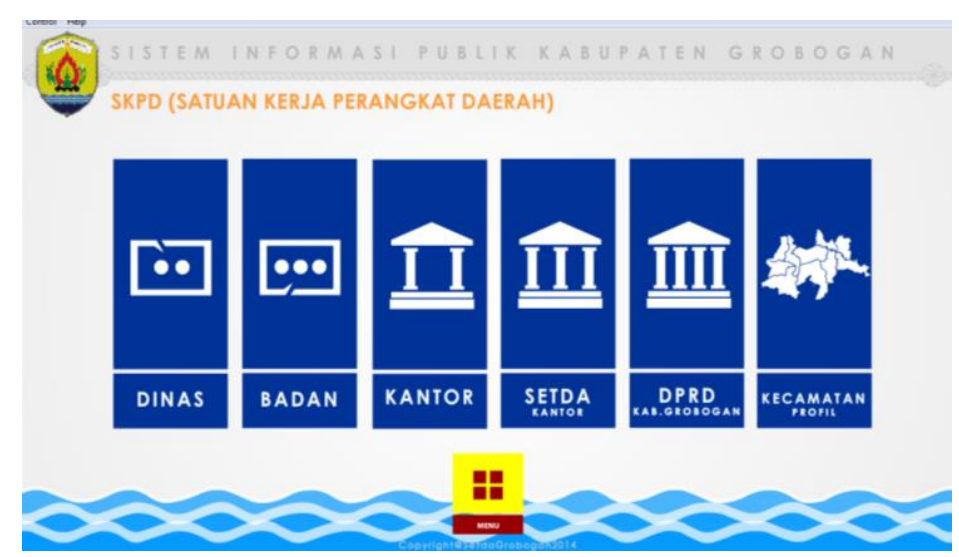

Gambar 11. Tampilan Menu SKPD

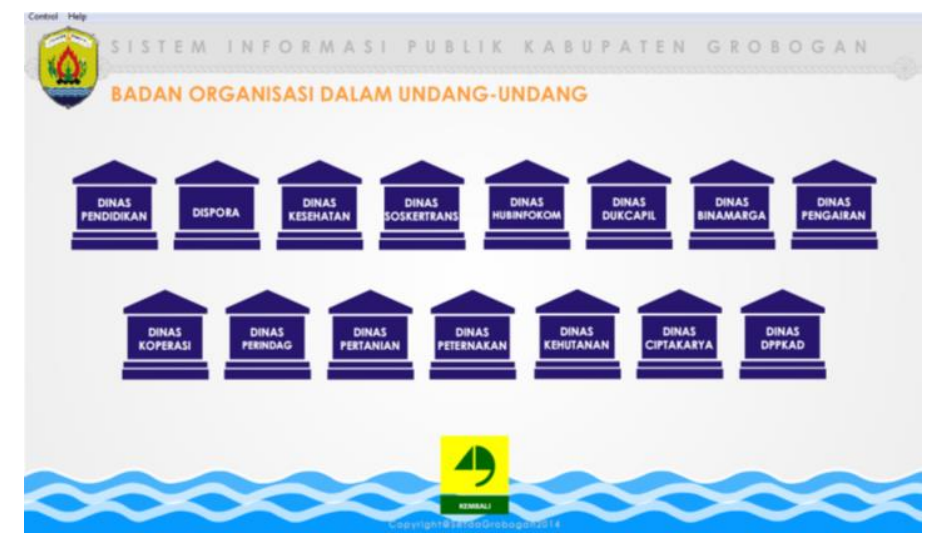

Gambar 12. Tampilan Sub Menu Dinas

i) Menu Galeri

Menu ini berisi mengenai dokumentasi-dokumentasi segala kegiatan-kegiatan yang ada di lingkungan kab. Grobogan

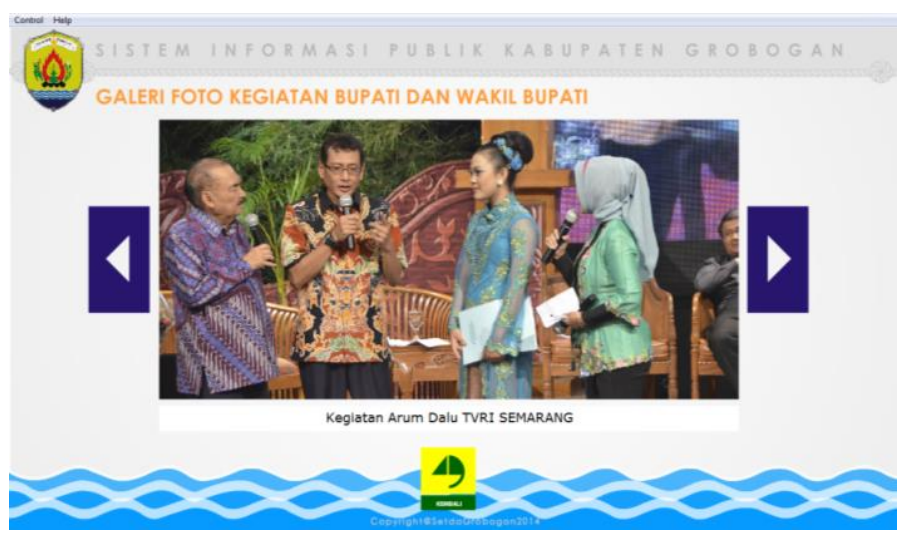

Gambar 13. Tampilan Menu Galeri 


\subsection{Kelebihan}

Interaktif media yang dirancang memiliki beberapa kelebihan dalam pelaksanaanya, diantaranya :

1. Interaktif media memberikan kenyamanan kepada masyarakat dalam memperoleh informasi.

2. Mampu menggantikan peranan manusia dalam pelayanan.

3. Interaktif media yang dirancang memiliki data yang valid karena semua datadata berasal dari instansi terkait.

4. Interaktif media didesain semenarik mungkin dan mudah dipahami oleh masyarakat umum.

5. Kedepannya dapat dikembangkan di berbagai media.

6. Informasi yang ada dapat diupdate kapan saja.

\section{KESIMPULAN}

Berdasarkan analisa pembuatan aplikasi media interaktif sistem informasi publik yang telah dilakukan, maka peneliti mengambil kesimpulan sebagai berikut :

1. Pelayanan publik haruslah dilakukan dengan sebaik-baiknya dan diupayakan dengan berbagai cara apapun untuk mendapatkan kepuasan publik. Dimana salah satu solusi untuk meningkatkan pelayanan publik yaitu dengan cara memanfaatkan kemajuan teknologi yang ada di era globalisasi sekarang ini.

2. Interaktif media dalam perancangan sistem informasi publik sangatlah diperlukan dalam upaya pelayanan terhadap publik.

3. dalam pelaksanaanya kedepan diperlukan koordinasi antar instansi terkait karena pembaharuan data harus dilakukan secara berkala untuk memberi informasi yang valid kepada masyarakat.

4. Perkembangan kedepannya interaktif media sistem informasi publik bisa diterapkan dalam media lainnya untuk meningkatkan pelayanan kepada masyarakat.

\section{DAFTAR PUSTAKA}

Adisasmita, Rahardjo. 2011. Pengelolaan Pendapatan \& Anggaran Daerah, Yogyakarta : Graha Ilmu.

Arief S Sadiman, dkk. 2006. Media Pendidikan. Jakarta: PT Raja Grafindo Persada.

Bovee, Courland. 1997. Business Communication Today,Prentice Hall: New York.

Dwiyanto, Agus, dkk. 2006. Reformasi Birokrasi Publik Di Indonesia, Pusat Studi Kependudukan dan Kebijakan, Yogyakarta: Universitas Gadjah Mada.

Effendy, Onong Uchjana. 2003. Ilmu Komunikasi Teori dan Praktek.Cetakan kesembilanbelas. Bandung: PT Remaja Rosdakarya

Gulo,W.(2005). Metodologi Penelitian. Jakarta:Grasindo.

Lenvine, Charless H., dkk. 1990. Publik Administration: Calenges, Choices, Consequences. Illions: Scott Foreman

Saragih, Ferdinand D. 2006. Menciptakan Pelayanan Publik yang Prima Melalui Metode Benchmarking Praktis. Jurnal Ilmu Administrasi dan Organisasi, Bisnis \& Birokrasi, Vol.14, No.3 (September).

Vardiansyah, Dani. 2004. Pengantar IImu Komunikasi. Cetakan kesatu. Bogor: Ghalia Indonesia. 